焉床好中球にAuer小体を認めた急性骨䯣性白血病の 1 例

\author{
荻䆶病院内科 \\ 大島 充一 $\diamond$ 塩原 保彦 浅野 真 \\ 慶応義熟大学医学部内科 \\ 青木 功 外山 圭助
}

\title{
A CASE OF ACUTE MYELOBLASTIC LEUKEMIA WITH AUER BODIES IN POLYMORPHONUCLEAR NEUTROPHILS
}

Shuichi OHShima, MD, Yasuhiko ShIOHARA, MD and Makoto AsAno, MD

Department of Internal Medicine, Ogikubo Hospital, Tokyo

Isao AOKI, MD and Keisuke ToYAMA, MD

Department of Internal Medicine, Keio University School of Medicine

\begin{abstract}
概要 多形核好中球にAuer小体を認めた急性骨髄性白血病 $\left(F A B\right.$ 分類 $\left.\mathrm{M}_{2}\right)$ の 1 例を報告する。 患者は，37才，男性。建築業で， 3 週間続いた発熱を主訴に荻㩁病院に入院した。 入院時, 白 血球 $6300 / \mathrm{cmm}$ で, 芽球 $5.5 \%$, 前骨髄球 $1.5 \%$, 好中球 $28 \%$ を認めた。骨䯣は芽球, 前骨䯣球に て占められていた。白血病細胞の細胞化学所見より $\mathrm{M}_{2}$ と診断した。末梢血や骨䯣の芽球拈よび 多形核好中球にAuer小体を有する細胞を認めた．電子顕改鏡的梌索では，Auer小体を有する好 中球では，二次顆粒が全く欠如している事が明らかになつた。これらの所見上り，この細胞が 白血病クローン由来である事を示するのと考觉られる。
\end{abstract}

\section{緒言}

Auer小体”の存在は，急性骨䯣性白血病の形態 学的診断根拠之考えられており, 通常骨䯣系幼若 細胞に認められる。しかしAuer小体を成熟好中球 に認めたとする報告が散見され3) 13)，近年電子顕 徽鏡的観察により，それらの病態生理が解明され つつある ${ }^{14) \sim 17)}$. 今回，多形核好中球 (polymorphonuclear cells, PMN) にAuer小体を認めた, 急性骨嘓性白血病(AML)の 1 例を経験したので， 電顕所見も含めて報告する。

\section{症例}

症例は37才の男性で，既往歴および家族歴に特 記すべき事なく，昭和58年 3 月初旬より発熱を認 め, 3 月 23 日当院受診, 血液検查にて, 佥血, 血 小板减少を指摘され，入院となつた。

入院時, 体格 - 栄養中等度, 脈拍 108 /分整, 血

[昭和59年 6 月 18 日受稿]

本論文の要旨は, 昭和 58 年 11 月 12 日，第 333 回日本内科学会 関東地方会に批いて発表した。
压 $90 / 58 \mathrm{mmHg}$, 体温 $38.5^{\circ} \mathrm{C}$, 眼䀫結膜貧血様, 眼 球結膜に黄疸は認めず，肝臓は助骨弓下 1 横指触 知，脾臓は触知せず，リンパ節は体表から触知し なかつた。胸骨吒打痛, 歯肉腫脹, 出血傾向は認 められなからた。

\section{入院時検查所見}

1）血液学的検查所見（表 1）：末梢血では， 高度の哖血，血小板数减少を認め，白血球数6300/ $\mathrm{cmm}$ で，血液像にて芽球 $5.5 \%$ ，前骨䯣球1.5\%を 認め, 一部の芽球, 前骨髄球にはAuer小体が認め られた。 また，写真 1 に示すよ 5 に, WrightGimsa染色で核に分葉を有し，成熟好中球と思わ れる細胞質内にAuer小体を認めた。骨髄は過形成 で，芽球 $25.6 \%$ ，前骨䯣球 $23.1 \%$ を認め，芽球， 前骨髄球，さらに成熟好中球と思われる細胞の一 部にAuer小体を認めた。白血病細胞は, peroxidase染色陽性で，特殊染色所見では，naphthol一 ASD-chloracetate esterase染色陽性, $\alpha$-naphtylbutylate-esterase染色は陰性である点から，FAB 
表 1. 血液検查所見

I. Peripheral blood
R.B.C.
Hb.
Ht.
Ret.
Platelet
W.B.C.
blast.
Promyelo.
myelo.
metamyelo.
stab.
seg.
lympho.
mono.
eosino.
baso
atypical lympho.
N.A.P. score
II. Coagulation system
APTT
PT .
Fibrinogen

$170 \times 104 / \mathrm{cmm}$
$6.7 \mathrm{~g} / \mathrm{dl}$
$20.0 \%$
$16 \% \%$
$6.2 \times 104 / \mathrm{cmm}$
$6300 / \mathrm{cmm}$
$5.5 \%$
$1.5 \%$
$2 \%$
$5.5 \%$
$11 \%$
$17 \%$
$57 \%$
$0.5 \%$
$0 \%$
$0 \%$
$0 \%$
100
30.45
$95.5 \%$
$500 \mathrm{mg} / \mathrm{dl}$

\begin{tabular}{|c|c|}
\hline III. Bone marrow & \\
\hline N.C.C. & $128,000 / \mathrm{cmm}$ \\
\hline Megakaryo. & $31 / \mathrm{cmm}$ \\
\hline M/E ratio & 26 \\
\hline blast. & $25.6 \%$ \\
\hline promyelo. & $23.1 \%$ \\
\hline myelo. & $20.4 \%$ \\
\hline metamyelo. & $8.8 \%$ \\
\hline stab. & $2.2 \%$ \\
\hline seg. & $4.2 \%$ \\
\hline lympho. & $4.8 \%$ \\
\hline mono. & $0.4 \%$ \\
\hline plasma. & $0.3 \%$ \\
\hline macrophage & $0.3 \%$ \\
\hline erythroblast & $3.7 \%$ \\
\hline mitosis & $0 \%$ \\
\hline $\begin{array}{l}\text { N. Chromosome } \\
46 \text { XY: } 5 \text { cells }\end{array}$ & \\
\hline V. Muramidase & \\
\hline serum & $66.1 \mu \mathrm{g} / \mathrm{m} \ell$ \\
\hline urine & $6.6 \mu \mathrm{g} / \mathrm{m} \ell$ \\
\hline $\mathrm{Vl}$. Histochemistry & of leukemic cells \\
\hline P.A.S. $(+)$ & o. $(+)$ \\
\hline
\end{tabular}
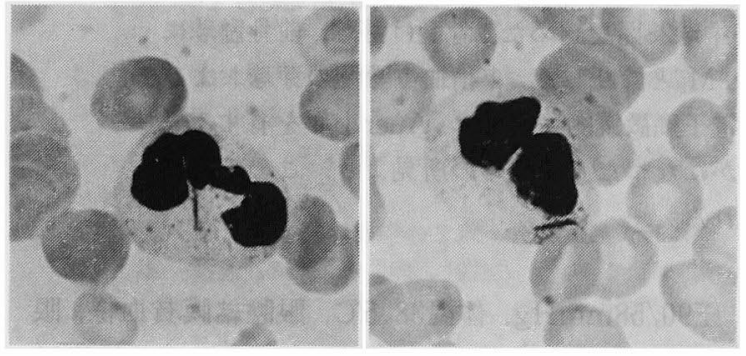

写真 1.Auer小体を有する多核好中球（末梢血）。 Wright-Gimsa染色.

分類 $\mathrm{M}_{2}$ のAMLと診断した。 この他，血清ムラミ ダーゼ值の中等度増加, 好中球アルカリフォス ファターゼ値の軽度低下を認めたが，染色体分析 では異常を認めなかつた。

2）一般検查所見（表 2 ）：血清LDHの著しい 高値を認める以外に異常は認めなかつた。

3）電子顕微鏡所見 (写真 2)：光顕にてAuer 小体を有した細胞のperoxidase反応の電顕写真 を示す。各細胞は, 核の分葉, 高度の核クロマチ ン凝集および，細胞質内にグリコーゲンを豊富に 認めるなどの点から, 成熟度の高い好中球と考党 られる.しかし, これらの細胞には, peroxidase 染色陽性の一次顆粒は多く認められるものの, 二 次顆粒は極小数か完全に欠損していた.

入院後経過（図 1)：白血病細胞についての特
表 2.一般検査所見

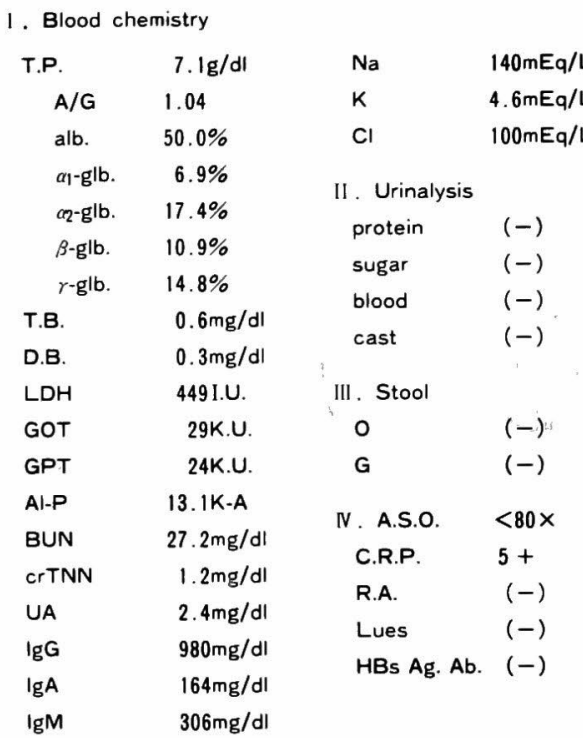

殊染色所見から, AML (FAB分類 $\left.\mathrm{M}_{2}\right)$ と診断し, aclasinomycin, 6-mercaptorurine, prednisolone, $\mathrm{N}^{4}$-behenoyl-1- $\beta$-D-arabinofuranosyl cytosine (BHAC)による寛解導入療法を開始し， 3 クール 施行後完全寛解導入が得られた。この時点では Auer小体を有する好中球は認められなくなつた。 上記薬物にてconsolidationを 2 クール施行後, 58 年 8 月退院し, 以後外来にて, 6-mercaptopurine 


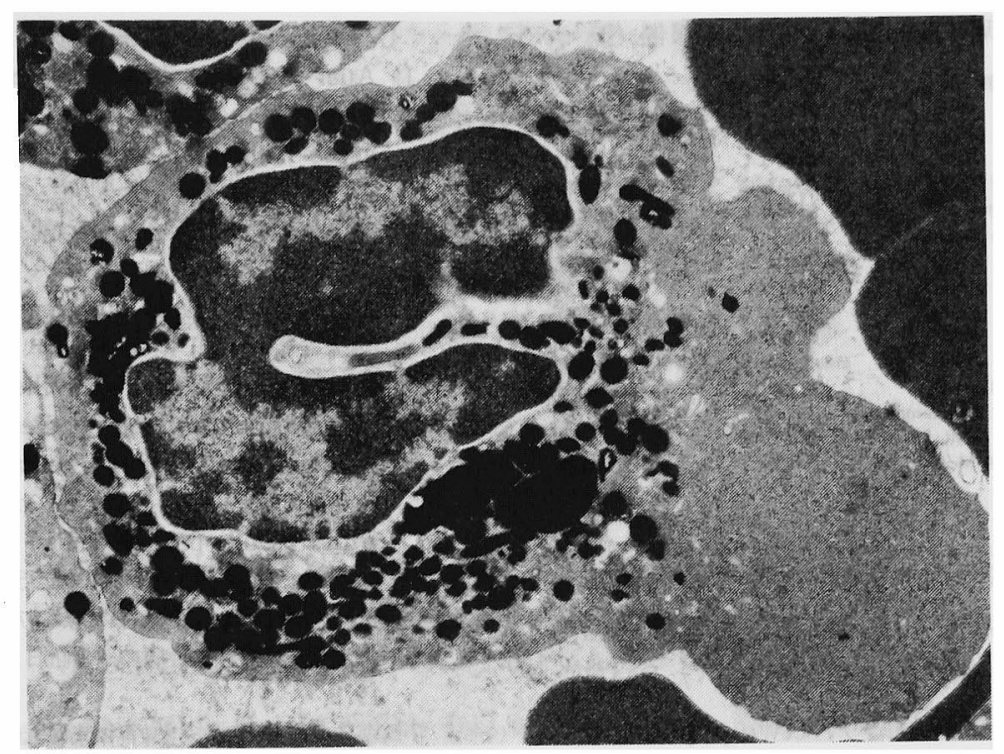

写真 2.Auer小体を有する多核好中球の電顕像，細胞質にperoxidase陽性のAuer 小 体, 一次顆粒を認めるが, 二次顆粒は欠如している.

（電影像7700倍）

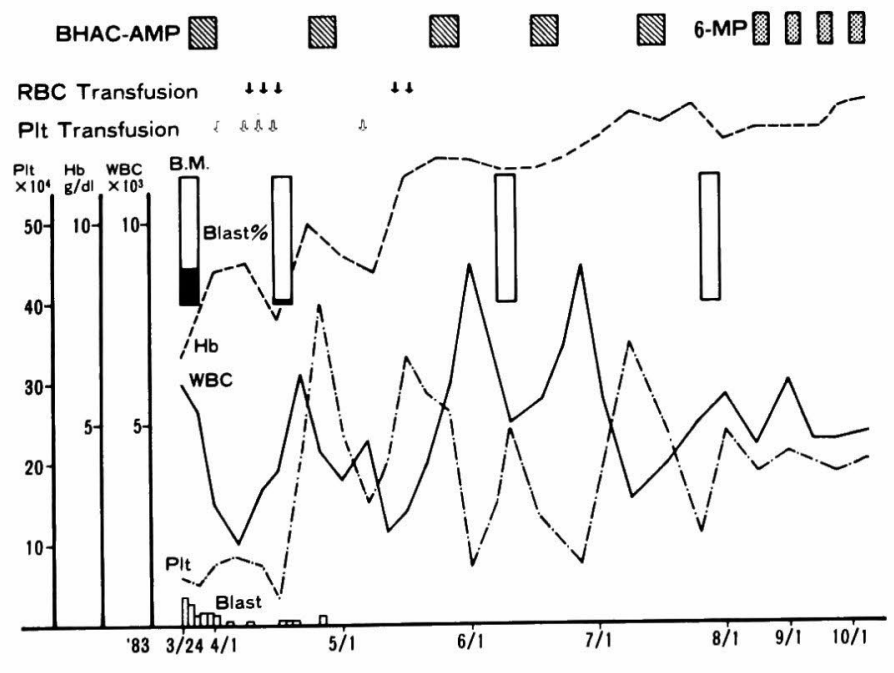

図 1. 臨床経過

による寛解維持療法を行ない, 現在なお完全寛解 を維持している.

\section{考案}

従来，骨髄系幼若細胞に現われると思われてい たAuer小体が, 成熟好中球にも認められたとする 症例の報告がみられ2) 17), その臨床的意義が注目 されている。本症例もAuer小体を含むPMNの存
在を認めたが, そのPMNの電顕所見から，核の分 葉, 核クロマチンの凝集, 核膜のperoxidase反応 陰性などの点を確認する事ができ，これらの細胞 の成熟度の高さが判明した。しかし, 細胞質につ いては，二次顆粒の形成不全または欠除といら点 から細胞質の未成熟度を示して扣り，核と細胞質 の成熟度に不均衡がみられた。これらAuer小体を 
表 3，好中球にAuer小体を認めた諸報告

\begin{tabular}{|c|c|}
\hline 年 & 報告者 \\
\hline 1968 & Davis et al \\
\hline 1969 & Leder et al \\
\hline 1978 & 松洞的 \\
\hline \multirow{2}{*}{1980} & 菻本ら \\
\hline & 今中ら \\
\hline 1981 & 今井䏨 \\
\hline \multirow[t]{5}{*}{1982} & 政崎 \\
\hline & 木本ら \\
\hline & 毛爱ら \\
\hline & 津男 \\
\hline & 若粀ら \\
\hline \multirow[t]{2}{*}{1983} & 因点5 \\
\hline & 网本ら \\
\hline
\end{tabular}

文 献

1) Auer J: Some histero undescribed structures found in the large lymphocytes of a case of acute leukemia. Amer J Med Sci 131: 1002, 1906.

2）井上 浩：アウェル小体二就テ、北越医学会雑誌 $39: 258,1924$.

3）相原信幸 : Beitrăge zur Kenntnis des Auerkörpers. Nagoya J Med Sci 14: 129, 1951.

4) Goodwin AF and Gloversville NY: Some new observations on Auer bodies in acute myelogenous leukemia. Fol Haematol 51: 359, 1934.

5) Leder $\mathrm{LD}$, et al: A case of acute leukemia with pseudo-pelger cells containing Auer bodies. Acta Haematol 42: 58, 1969.

6）松岡清幸, 他：成熟好中球にフウエル小体を認め た急性骨髄性白血病の一例. 日血会誌 $41: 1014$, 1978.

7）森本幸治，他：成熟好中球にAuer小体を認めた急 性白血病の一完全緩解例。襙床血液 $21: 680$, 1980.

8）今井忠彦，他：成熟好中球にもフウエル小体を認 め染色体分析で, No. 13のモノソミーを諗めた急 性骨䯣性白血病の一例。日血会誌 $44: 1070$, 1981.

9) Davis AR, et al: Auer bodies in mature neutrophils. JAMA 203: 895, 1968.

10）磯崎栄光，他：AMLの成熟好中球にAuer小体を 認めた一症例。衛生検査 $31: 450 ， 1982$.

11）毛受弘親，他：末梢血成熟好中球にアウエル小体 を諗めたAMLの一例。日血会誌 $45 ： 1134,1982$.

12）津田昌一郎，他：成熟好中球にアウエル小体を認 めた $8 / 21$ 転座型急性骨㖪性白血病の 1 症例. 日血 会誌 $45: 1147,1982$.

13）若杉和義，他：成熟好中球にAuer小体を認めた非 定型性白血病の一例. 臨床血液 $23: 1959,1982$.

14）岡本真一郎, 他：成熟好中球にAuer小体を認めた 急性骨骮単球性白血病の一例. 臨床血液 25 ： 1686, 1984.

15) Bainton DF, et al: Abnormalities in granule formation in acute myelogenous leukemia. Blood $49: 693,1977$.

16）今中芓信，他：成熟好中球にAuer小体を認めた Smouldering acute leukemia一細胞学的所見を 中心に。臨床血液 21(補1)：34：1978.

17）木本元治，他：成熟多核好中球にAuer小体を認め た急性骨髄性白血病の一症例. 臨床血液 23 : 666, 1982. 